\title{
Protein deficiency, but not zinc deficiency, reduces recovery of type 1 and type 2 muscle fibre diameters in the gastrocnemius muscle of growing rats
}

\author{
Alexia L. V. Prescod ${ }^{1}$, William C. Halliday ${ }^{2,3}$ and Carla G. Taylor ${ }^{1 *}$ \\ ${ }^{1}$ Department of Human Nutritional Sciences, University of Manitoba, Winnipeg, MB, Canada R2H $2 A 6$ \\ ${ }^{2}$ The Hospital for Sick Children, Toronto, ON, Canada \\ ${ }^{3}$ Department of Laboratory Medicine and Pathobiology, University of Toronto, Toronto, ON, Canada
}

(Received 3 July 2010 - Revised 5 January 2011 - Accepted 23 January 2011 - First published online 27 April 2011)

\section{Abstract}

The present study examines the effects of protein- and energy-type malnutrition in combination with Zn deficiency on the growth, serum insulin-like growth factor-1 (IGF-1), gastrocnemius muscle mass and fibre diameter of growing rats during a deficiency phase followed by nutritional rehabilitation. Rats (3-weeks old) were randomly assigned to baseline, or Zn-deficient ( $\mathrm{Z},<1 \mathrm{mg} Z \mathrm{Zn} / \mathrm{kg}$ ), protein-deficient ( $\mathrm{P}$, $20 \mathrm{~g}$ protein $/ \mathrm{kg}$ ), combined $\mathrm{Zn}$ - and protein-deficient (ZP), energy-deficient (E, feed intake pair-fed to Z) or control (C, $30 \mathrm{mg} \mathrm{Zn} / \mathrm{kg}$ and $170 \mathrm{~g}$ protein $/ \mathrm{kg}$ ) groups for a 3-week deficiency phase, followed by a 3-week repletion phase with the control diet. ATPase histochemical staining at pH 9.4 was used to differentiate type 1 and type 2 muscle fibres. After the deficiency phase, the ZP and P groups had lower body weight and smaller gastrocnemius muscle mass than the $Z$ and $E$ groups. Type 1 and 2 muscle fibre diameters (T1- and T2-MFD, respectively) were reduced in the $\mathrm{ZP}, \mathrm{P}$ and $\mathrm{Z}$ groups compared with the $\mathrm{E}$ and $\mathrm{C}$ groups. Serum $\mathrm{Zn}$ was reduced in the $\mathrm{ZP}, \mathrm{P}$ and $\mathrm{Z}$ groups, but serum IGF-1 was lowest in the $Z$ and $E$ groups. After the repletion phase, T1-MFD did not recover in the P and E groups nor T2-MFD in the $\mathrm{P}$ group, despite the $\mathrm{P}$ and $\mathrm{E}$ groups having a better recovery of body weight. In summary, previous protein deficiency, but not $\mathrm{Zn}$ deficiency, limited the recovery of both T1- and T2-MFD during nutritional repletion. The quality of skeletal muscle recovery in the malnourished groups was not associated with body weight, muscle mass, serum $\mathrm{Zn}$ or IGF-1 concentrations.

Key words: Zinc: Insulin-like growth factor-1: Muscle: Rats

Undernutrition leading to poor anthropometric status and $\mathrm{Zn}$ deficiency remain significant global risk factors for death and disease. The $\mathrm{WHO}^{(1)}$ reports that globally, childhood underweight is the leading cause of disease burden, while $\mathrm{Zn}$ deficiency is the 17 th leading cause of both death and disability. Children recovering from protein-energy malnutrition (PEM) do not regain muscle mass as efficiently as fat mass $^{(2,3)}$, and there may be histological differences in the muscle structure, including a significantly smaller muscle fibre size than age- and sex-matched controls ${ }^{(4,5)}$.

During nutritional rehabilitation, high rates of weight gain have been associated with suboptimal serum $\mathrm{Zn}$ concentrations and a high cost of growth, indicating adipose tissue synthesis $^{(6)}$. Addition of $\mathrm{Zn}$ to the refeeding regimen of children with PEM has decreased the cost of growth, indicating muscle tissue synthesis ${ }^{(7)}$ and increased $\mathrm{N}$ retention ${ }^{(8)}$. Similarly, it has been shown that adequate dietary $\mathrm{Zn}$ is required for improved weight gain and lean body mass during recovery from undernutrition in rodent models ${ }^{(9,10)}$.
These findings have led to questions about the interaction of $\mathrm{Zn}$ with various anabolic hormones and peptides, and the quality of lean mass recovery.

Insulin-like growth factor-1 (IGF-1) is an anabolic peptide produced in many tissues including the liver and skeletal muscle. In skeletal muscle, IGF-1 has been associated with normal growth ${ }^{(11)}$, hypertrophy ${ }^{(12)}$ and repair ${ }^{(13)}$. Serum IGF1 concentrations are influenced by nutritional state, particularly PEM and $\mathrm{Zn}$ status ${ }^{(14-16)}$. Serum IGF-1 concentrations are reduced in models of severe energy restriction (50\% of ad libitum intake) or protein restriction ( $5 v .15 \%$ lactalbumin) in young growing rats ${ }^{(17)}$. Supplemental $\mathrm{Zn}$ improves serum IGF-1 levels in children with clinical Zn deficiency ${ }^{(14,16)}$; however, IGF-1 infusion is not effective for restoring carcass growth in protein-restricted young rats ${ }^{(18)}$, indicating that it is the combination of nutrient substrate availability and IGF-1 that is important. Serum IGF-1 concentrations are reduced in weanling rats fed a $\mathrm{Zn}$-deficient diet ( $<1 \mathrm{mg} \mathrm{Zn/kg} \mathrm{diet),} \mathrm{com-}$ pared with pair-fed control rats ${ }^{(19,20)}$, and in force-fed $Z$ rats

Abbreviations: B, baseline; C, control; E, energy deficient; IGF-1, insulin-like growth factor-1; MFD, muscle fibre diameter; P, protein deficient; PEM, protein-energy malnutrition; T1-MFD, type 1 muscle fibre diameter; T2-MFD, type 2 muscle fibre diameter; Z, zinc deficient; ZP, Zn- and protein-deficient. 
that receive the same amount of energy and protein as the control group ${ }^{(21)}$. Furthermore, serum IGF-1 has been reported to respond to increasing $\mathrm{Zn}$ intake, but not protein intake, when rats have previously been fed a combined $\mathrm{Z}$ and low-protein diet ${ }^{(19)}$. Although $\mathrm{Zn}$ status and serum IGF1 have been studied in relation to growth, liver and bone metabolism, less is known about the interaction of $\mathrm{Zn}$ status and serum IGF-1 with skeletal muscle.

The present study was designed to address the effects of different types of malnutrition in combination with $\mathrm{Zn}$ deficiency on growth and skeletal muscle development during a deficiency phase followed by nutritional rehabilitation. An important goal was to determine whether recovery from malnutrition occurs equally among the different levels of cellular organisation, i.e. from whole body to muscle histology. Since IGF-1 is an important factor in skeletal muscle physiology $^{(22)}$ and is sensitive to $\mathrm{Zn}$ status ${ }^{(17,19,20)}$, it has been hypothesised that previous $\mathrm{Zn}$ deficiency may be more detrimental to the recovery of muscle mass and muscle fibre diameter (MFD) than previous macronutrient deficiency of protein or energy. The objectives of the study were to (1) investigate the effects of $\mathrm{Zn}$, protein and energy deficiencies on growth, body composition, gastrocnemius muscle weight and fibre diameter in relation to serum IGF-1 and Zn concentrations (deficiency phase) and (2) examine these parameters after a standard $(30 \mathrm{mg} \mathrm{Zn} / \mathrm{kg}$ diet) recovery diet (repletion phase). Weanling rats were chosen for the present study as they are poised for rapid growth and development, analogous to children. Zn deficiency was studied alone and in combination with protein deficiency, as inadequate protein intake is a major contributor to inadequate $\mathrm{Zn}$ intake in the human population $^{(23)}$. MFD was used to assess the quality of muscle repair and hypertrophy ${ }^{(24)}$.

\section{Experimental methods}

\section{Design}

Male weanling Sprague-Dawley rats (3 weeks old, $n$ 88; Charles River Laboratories, St Constant, PQ, Canada) were used to conduct the 6-week study which consisted of a deficiency phase ( $0-3$ weeks) followed by a repletion phase (4-6 weeks). The rats were randomly assigned to a baseline (B) group and killed on day 0 ( $n$ 8), or to one of the following five dietary treatment groups (sixteen animals per group) and fed for 3 weeks: $Z n$ - and protein-deficient (ZP, $20 \mathrm{~g}$ protein $+<1 \mathrm{mg} \mathrm{Zn/kg} \mathrm{diet);} \mathrm{Zn-deficient} \mathrm{(Z,}$ $170 \mathrm{~g}$ protein $+<1 \mathrm{mg} \mathrm{Zn/kg} \mathrm{diet);} \mathrm{protein-deficient} \mathrm{(} \mathrm{P}$, $20 \mathrm{~g}$ protein $+30 \mathrm{mg} \mathrm{Zn} / \mathrm{kg} \mathrm{diet})$; energy-deficient $(\mathrm{E}, 170 \mathrm{~g}$ protein $+30 \mathrm{mg} \mathrm{Zn/kg} \mathrm{diet);} \mathrm{control} \mathrm{(C,} 170 \mathrm{~g}$ protein +30 $\mathrm{mg} \mathrm{Zn} / \mathrm{kg}$ diet). The diet composition (Table 1) was based on the AIN-93G formulation ${ }^{(25)}$. The $\mathrm{ZP}, \mathrm{Z}, \mathrm{P}$ and $\mathrm{C}$ groups were given free access to the diet, whereas the $\mathrm{E}$ rats were individually pair-fed the amount of diet consumed by the $\mathrm{Z}$ rats on the previous day, and this was equivalent to $50 \%$ of the cumulative feed intake by the $\mathrm{C}$ group during the deficiency phase. Thus, the E group was a pair-fed control group to control for the anorexia of $\mathrm{Zn}$ deficiency, and it was a model for energy deficiency via diet restriction. At the end of the 3-week deficiency phase, tissues were collected from eight rats per group. The remaining forty rats entered the 3-week recovery phase and were given free access to the control diet containing $30 \mathrm{mg} \mathrm{Zn} / \mathrm{kg}$ diet. During the study, the rats were housed in stainless-steel wire-bottomed cages with free access to double-distilled water from a polyethylene bottle with a stainless-steel sipper tube. Feed intake was determined daily and the rats were weighed weekly. Animal care was provided in accordance with a protocol approved by the University of Manitoba Animal Care Committee in accordance with Canadian Guidelines for the Care and Use of Laboratory Animals ${ }^{(26)}$.

\section{Tissue collection}

Rats were asphyxiated with $\mathrm{CO}_{2}$, weighed and decapitated for the collection of trunk blood. Then, one gastrocnemius muscle was excised and frozen in isopentane $\left(-150^{\circ} \mathrm{C}\right)$ cooled in liquid $\mathrm{N}_{2}^{(27,28)}$. The other gastrocnemius muscle and inguinal fat pads were excised, weighed and frozen in liquid $\mathrm{N}_{2}$. Tissues and serum were stored at $-80^{\circ} \mathrm{C}$.

\section{Biochemical assays}

Serum IGF-1 was determined using a rat serum IGF-1 double antibody RIA kit (DSL-2900; Diagnostic Systems Laboratories, Inc., Webster, TX, USA) and serum albumin using a kit (no. 631; Sigma Diagnostics, St Louis, MO, USA). Liver lipid, and $\mathrm{Zn}$ concentrations in serum, femur and diets were determined as described previously ${ }^{(29)}$.

\section{Muscle histology}

Muscle fibre types were identified by ATPase activity at $\mathrm{pH}$ $9 \cdot 4^{(24,27,28)}$. Briefly, cross-sectional muscle sections $(10 \mu \mathrm{m})$ were incubated in a $\mathrm{CaCl}_{2}$ and sodium bicarbonate enhancing

Table 1. Diet formulation

\begin{tabular}{lcccc}
\hline Ingredients $(\mathrm{g} / \mathrm{kg}) \dagger$ & $\mathrm{ZP}$ & $\mathrm{Z}$ & $\mathrm{P}$ & $\mathrm{C}$ \\
\hline Dextrose & $851 \cdot 3$ & $664 \cdot 6$ & $841 \cdot 3$ & $654 \cdot 6$ \\
Egg white & 25 & $212 \cdot 5$ & 25 & $212 \cdot 5$ \\
Soyabean oil & 70 & 70 & 70 & 70 \\
Zn-free mineral mix $\ddagger$ & 35 & 35 & 35 & 35 \\
Zn pre-mix§ & 0 & 0 & 10 & 10 \\
Potassium phosphate\| & $6 \cdot 2$ & $5 \cdot 4$ & $6 \cdot 2$ & $5 \cdot 3$ \\
Vitamin mix 9 & 10 & 10 & 10 & 10 \\
Choline & $2 \cdot 5$ & $2 \cdot 5$ & $2 \cdot 5$ & $2 \cdot 5$ \\
\hline
\end{tabular}

ZP, zinc- and protein-deficient; $Z$, zinc-deficient; $P$, protein-deficient; $C$, control diet.

* The energy-deficient group was fed restricted amounts of the $C$ diet as described in the Methods section. Formulations are based on the American Institute of Nutrition (AIN)-93G diet for growing rats; the $\mathrm{Zn}$ content of each diet was verified by atomic absorption spectroscopy as described previously ${ }^{(29)}$.

† Diet ingredients were purchased from Harlan Teklad (Madison, WI, USA) with the exception of soyabean oil (Vita Health, Winnipeg, MB, Canada) and dextrose (Moonshiners, Winnipeg, MB, Canada).

$\ddagger$ AlN-93M Zn-free mineral mix (Harlan Teklad).

$\S \mathrm{Zn}$ pre-mix contained $5.77 \mathrm{~g}$ of zinc carbonate/kg dextrose.

|| Adjustment for equivalency to the AIN-93G mineral mix and differing amounts of egg white.

ๆ AIN-93 vitamin mix (Harlan Teklad). 
solution ( $15 \mathrm{~min}$ at room temperature) and an alkaline solution of $\mathrm{Ca}$ and ATP $\left(20 \mathrm{~min}\right.$ at $\left.37^{\circ} \mathrm{C}\right)$. The ATPase enzyme splits the terminal phosphate from ATP, and the free phosphate is immediately bound by $\mathrm{Ca}$, creating calcium phosphate that is insoluble in the alkaline solution and which is deposited at the site of ATPase activity. The muscle sections were rinsed in three changes of $1 \% \mathrm{CaCl}_{2}$, incubated with $2 \%$ cobalt chloride for $3 \mathrm{~min}$ (Co replaces Ca forming cobalt phosphate), and rinsed with six changes of distilled water. The muscle sections were exposed to $1 \%$ ammonium sulphate for $1 \mathrm{~min}$, resulting in insoluble black cobaltous sulphide at the original site of ATPase activity. Thus, type 1 (slow twitch) and type 2 (fast twitch) muscle fibres appear light (low ATPase activity) or dark (high ATPase activity) in colour, respectively. Finally, the slides were washed six times with distilled water and lightly counterstained with eosin. Digital images of the muscle sections were used to determine MFD ( $>75$ fibres/rat) with IBAS software (version 2.0; Kontron Electronics, Kaufbeuren, Germany) calibrated with a micrometre slide.

In addition, the muscle samples were subjected to haematoxylin and eosin staining for identification of histological structures, and modified Gomori trichrome for assessment of mitochondria, oil red $O$ for the presence of TAG and neutral fat in muscle, and periodic acid Schiff with and without diastase staining for detection of glycogen ${ }^{(28)}$.

\section{Statistical analysis}

Data were analysed by ANOVA (SAS software 6.04; SAS Institute, Cary, NC, USA). Duncan's multiple-range test was used for means testing. Differences were deemed significant at $P<0.05$.

\section{Results}

In the present study, the main effects of diet, time and diet $X$ time interaction were significant $(P<0.05)$ for all parameters except the gastrocnemius muscle:body weight ratio (no significant main effects) and type 2 MFD (T2-MFD; diet and diet $\times$ time interaction were significant but not time) as described below. The significant diet $\times$ time interaction for all parameters (except the gastrocnemius muscle:body weight ratio) means that the response of a particular diet regimen ( $\mathrm{ZP}, \mathrm{P}, \mathrm{Z}, \mathrm{E}, \mathrm{C})$ was different depending on time (deficiency and repletion phases), as described in the following sections.

The feed intake of the $\mathrm{C}$ group was greater $(P<0.05)$ than that of the other groups during the deficiency and repletion phases (Table 2). During repletion, the feed intake of the $\mathrm{Z}$ group was greater $(P<0.05)$ than that of the $\mathrm{ZP}$ and $\mathrm{P}$ groups while the E group was intermediate. Feed efficiency during the deficiency phase was highest $(P<0.05)$ in the $\mathrm{E}$ group, followed by the $\mathrm{P}$ and $\mathrm{C}$ groups, and then the $\mathrm{Z}$ group. The ZP group had a negative feed efficiency during the deficiency phase; however, during repletion, this group had a greater $(P<0.05)$ feed efficiency than the $\mathrm{P}, \mathrm{E}$ and $\mathrm{C}$ groups.

At the end of the deficiency phase, the $\mathrm{ZP}$ and $\mathrm{P}$ groups had body weights that were $34 \%$ of the $\mathrm{C}$ group $(P<0.05)$, while the $\mathrm{Z}$ and $\mathrm{E}$ groups had body weights that were $50-56 \%$ of the $\mathrm{C}$ group $(P<0.05$; Fig. 1(A)). At the end of the repletion phase, the $\mathrm{ZP}$ and $\mathrm{Z}$ groups had body weights that were 66-69\% of the $\mathrm{C}$ group $(P<0.05)$ and the $\mathrm{P}$ and $\mathrm{E}$ groups had body weights that were $78-80 \%$ of the $C$ group $(P<0.05)$.

Adipose stores were monitored via the inguinal fat pad weight, and no fat pads could be excised from the E group at the end of the deficiency phase, confirming energy-type malnutrition. The inguinal fat pad:body weight ratio of the $\mathrm{Z}$ group was similar to the $\mathrm{B}$ group and lower $(P<0.05)$ than the $\mathrm{ZP}, \mathrm{P}$ and $\mathrm{C}$ groups (Fig. 1(B)). After the repletion phase, the $Z$ group had approximately two-thirds $(P<0.05)$ the inguinal fat pad:body weight ratio of the $\mathrm{P}$ group.

After the deficiency phase, the ZP and P groups had elevated $(P<0.05)$ liver lipid concentrations (Fig. 1(C)) and lower $(P<0.05)$ serum albumin concentrations (Fig. 2(A)), compared with the other groups including $\mathrm{B}$, confirming protein-type malnutrition.

At the end of the deficiency phase, the $\mathrm{Z}$ and $\mathrm{E}$ groups had lower $(P<0.05)$ serum IGF-1 concentrations than all the other groups including $\mathrm{B}$ (Fig. 2(B)). The serum IGF-1 concentrations of the $\mathrm{Z}$ and $\mathrm{E}$ groups were 11 and $22 \%$, respectively, of the $C$ group. The serum IGF-1 concentration of the $\mathrm{P}$ group was higher $(P<0.05)$ than the $\mathrm{B}$ and $\mathrm{ZP}$ groups, but it was lower $(P<0.05)$ than the $\mathrm{C}$ group. Following the repletion phase, all groups had similar serum IGF-1 concentrations.

Table 2. Effects of dietary zinc, protein and energy deficiencies and repletion on cumulative feed intake and feed efficiency of growing rats (Mean values with their standard errors)

\begin{tabular}{|c|c|c|c|c|c|c|c|c|c|c|}
\hline & \multicolumn{2}{|c|}{$\mathrm{ZP}$} & \multicolumn{2}{|c|}{$\mathrm{P}$} & \multicolumn{2}{|c|}{ Z } & \multicolumn{2}{|c|}{$\mathrm{E}$} & \multicolumn{2}{|c|}{$\mathrm{C}$} \\
\hline & Mean & SEM & Mean & SEM & Mean & SEM & Mean & SEM & Mean & SEM \\
\hline \multicolumn{11}{|c|}{ Cumulative feed intake ( $\mathrm{g} / 3$ weeks) } \\
\hline Deficiency phase & $110^{\mathrm{e}}$ & 5 & $127^{\mathrm{e}}$ & 20 & $119^{\mathrm{e}}$ & 10 & $117^{\mathrm{e}}$ & 9 & $235^{\mathrm{d}}$ & 43 \\
\hline Repletion phase & $408^{\mathrm{C}}$ & 15 & $424^{\mathrm{C}}$ & 56 & $484^{\mathrm{b}}$ & 75 & $448^{\mathrm{b}, \mathrm{c}}$ & 52 & $668^{a}$ & 65 \\
\hline \multicolumn{11}{|c|}{ Feed efficiency ratio $(\mathrm{g} / \mathrm{g})^{\star}$} \\
\hline Deficiency phase & $-0.016^{d}$ & 0.008 & $0.507^{\mathrm{b}}$ & 0.040 & $0.353^{\mathrm{c}}$ & 0.024 & $0.610^{\mathrm{a}}$ & 0.024 & $0.458^{\mathrm{b}}$ & 0.015 \\
\hline Repletion phase & $0.507^{\mathrm{a}}$ & 0.014 & $0.437^{\mathrm{b}, \mathrm{c}}$ & 0.019 & $0.478^{a, b}$ & 0.019 & $0.428^{\mathrm{b}, \mathrm{c}}$ & 0.016 & $0.392^{c}$ & 0.016 \\
\hline
\end{tabular}

$\mathrm{ZP}, \mathrm{Zn}$ - and protein deficient; $\mathrm{P}$, protein deficient; $\mathrm{Z}$, Zn deficient; $\mathrm{E}$, energy deficient; C, control diet.

$\mathrm{a}, \mathrm{b}, \mathrm{c}, \mathrm{d}, \mathrm{e}$ Mean values with unlike superscript letters were significantly different $(P<0.05)$.

${ }^{*}$ Feed efficiency ratio $=$ body weight gain $(\mathrm{g}) /$ feed intake $(\mathrm{g})$. Main effects (diet, time and diet $\times$ time) were significant for each parameter $(P<0 \cdot 05)$. 

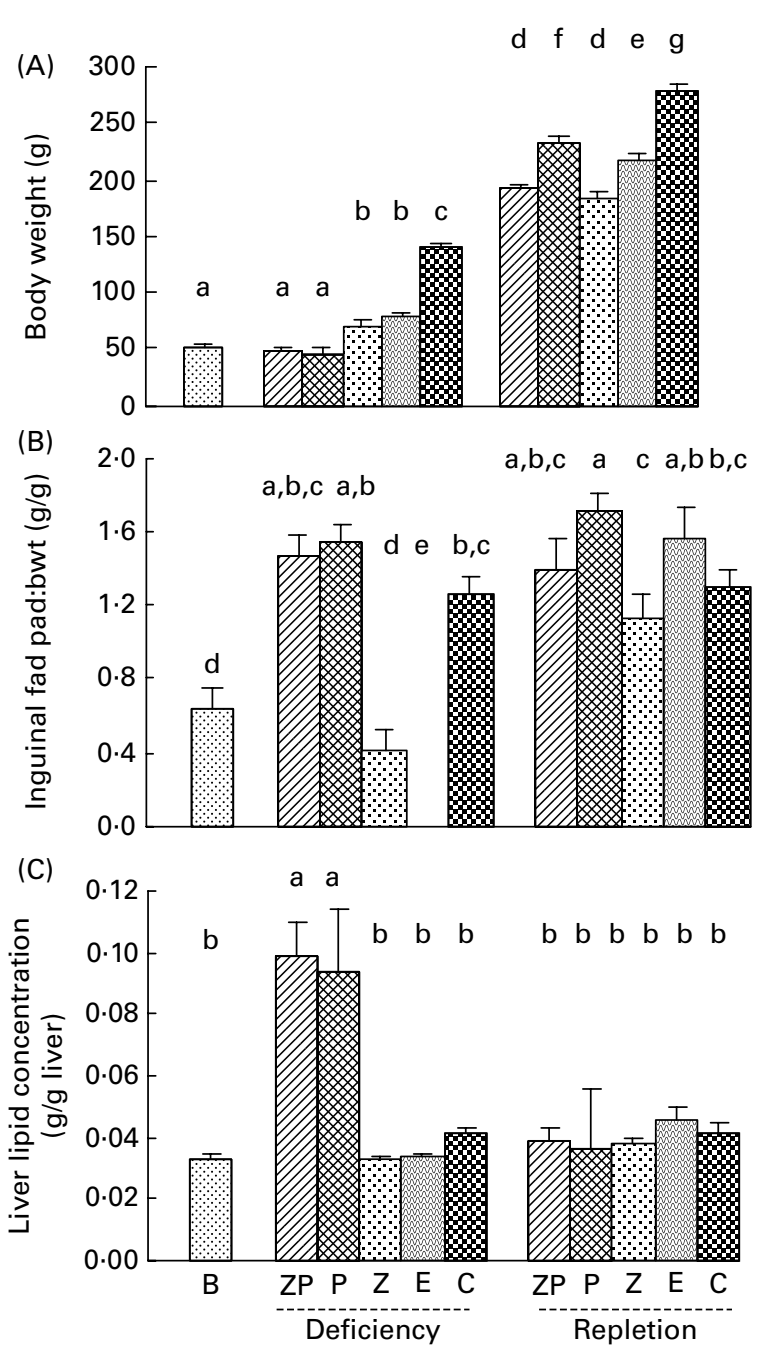

Fig. 1. Effects of dietary zinc, protein and energy deficiencies and repletion on (A) body weight (bwt), (B) inguinal fat pad:bwt ratio and (C) liver lipid concentration in growing rats. Values are means, with their standard errors represented by vertical bars (eight animals per group). Main effects (diet, time and diet $\times$ time) were significant for each parameter $(P<0.05)$. $a, b, c, d, e, f, g$ Mean values with unlike letters were significantly different from each other $(P<0.05)$. B, baseline; ZP, zinc- and protein-deficient; $\mathrm{P}$, proteindeficient; Z, zinc-deficient; E, energy-deficient; C, control.

Following the deficiency phase, the ZP, $\mathrm{P}$ and $\mathrm{Z}$ groups had serum $\mathrm{Zn}$ concentrations that were similar and 51-81\% lower $(P<0.05)$ than the $\mathrm{B}, \mathrm{E}$ and $\mathrm{C}$ groups (Fig. 3(A)). After the repletion phase, all groups had similar serum $\mathrm{Zn}$ concentrations. The changes in serum $\mathrm{Zn}$ concentration were paralleled by the changes in femur $\mathrm{Zn}$ concentration (Fig. 3(B)). Despite similar dietary $\mathrm{Zn}$ intake, the $\mathrm{ZP}$ group had a higher $(P<0.05)$ femur $\mathrm{Zn}$ concentration than the $\mathrm{Z}$ group.

Gastrocnemius muscle weights after the deficiency and recovery phases (Fig. 4(A)) paralleled body weight as there were no differences when gastrocnemius muscle mass was expressed relative to body weight (Fig. 4(B); no significant main effects).

ATPase histochemical staining at $\mathrm{pH} 9.4$ of the gastrocnemius muscle was used to differentiate type 1 (low ATPase activity, light in colour) and type 2 (high ATPase activity, dark in colour) muscle fibres after the deficiency (Fig. 5) and repletion (Fig. 6) phases. After the deficiency phase, the type 1 MFD (T1-MFD) of the $C$ group increased 1.3-fold $(P<0.05)$ from the 3 -week-old $\mathrm{B}$ group (Fig. 4(C)). The ZP, $\mathrm{P}$ and $\mathrm{Z}$ groups had T1-MFD values that were not different from the $\mathrm{B}$ group but were $80-82 \%$ of the $\mathrm{C}$ group $(P<0.05)$. The $\mathrm{E}$ and $\mathrm{C}$ groups had similar T1-MFD values that were greater $(P<0.05)$ than the other groups. By the end of the repletion phase, the T1-MFD of the $C$ group had increased $1 \cdot 2$-fold $(P<0.05)$ from the 6-week-old $\mathrm{C}$ group value. The T1-MFD values of the $\mathrm{P}$ and $\mathrm{E}$ groups were 16 and $9 \%$, respectively, less $(P<0.05)$ than the $C$ group. The T1-MFD values of the $\mathrm{ZP}$ and $\mathrm{Z}$ groups were not different from that of the $\mathrm{C}$ group. At the end of the deficiency phase, the T2-MFD of the $C$ group had increased by 1.5 -fold $(P<0.05)$ from the $\mathrm{B}$ group, and it was higher $(P<0.05)$ than the other groups (Fig. 4(D)). The 6-week-old ZP, P and $Z$ groups had T2-MFD values that were not different from the 3-week-old B group but were $69-78 \%$ of the $C$ group $(P<0.05)$. The T2-MFD of the $\mathrm{E}$ group was similar to the $\mathrm{Z}$ group and $14 \%$ less $(P<0.05)$ than the $C$ group. After the repletion phase, the T2-MFD of the $\mathrm{ZP}, \mathrm{Z}$ and $\mathrm{E}$ groups were not different from that of the $\mathrm{C}$ group. Only the $\mathrm{P}$ group had a smaller $(P<0.05)$ T2-MFD that was $15 \%$ less than the $\mathrm{C}$ group. There were no differences among groups for the other histological assessments of mitochondria, neutral fat or glycogen in skeletal muscle (data not shown).
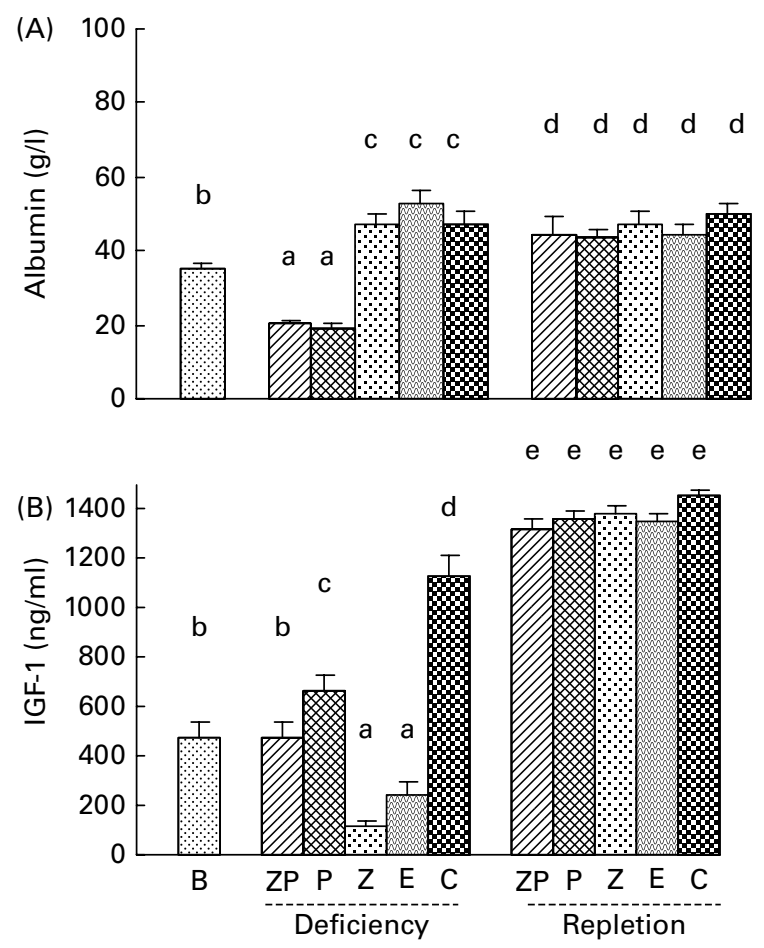

Fig. 2. Effects of dietary zinc, protein and energy deficiencies and repletion on serum (A) albumin and (B) insulin-like growth factor-1 (IGF-1) concentrations in growing rats. Values are means, with their standard errors represented by vertical bars (eight animals per group). Main effects (diet, time and diet $\times$ time) were significant for each parameter $(P<0.05)$. ${ }^{a, b, c, d, e}$ Mean values with unlike letters were significantly different from each other $(P<0.05)$. B, baseline; $Z \mathrm{P}$, zinc- and protein-deficient; $\mathrm{P}$, protein-deficient; $\mathrm{Z}$, zinc-deficient; $\mathrm{E}$, energy-deficient; $\mathrm{C}$, control. 
(A)

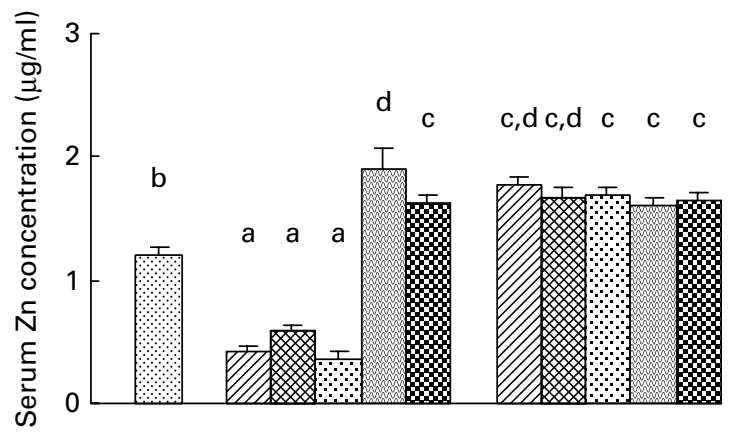

(B)

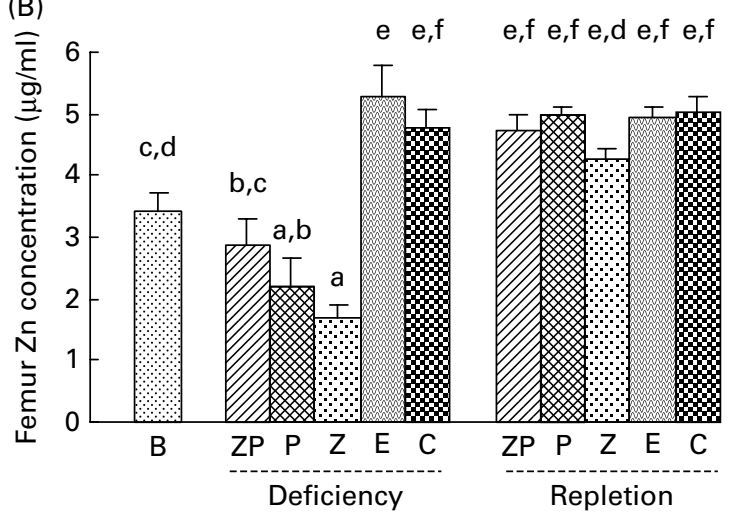

Fig. 3. Effects of dietary zinc, protein and energy deficiencies and repletion on (A) serum and (B) femur zinc concentrations in growing rats. Values are means, with their standard errors represented by vertical bars (eight animals per group). Main effects (diet, time and diet $\times$ time) were significant for each parameter $(P<0.05) .{ }^{\mathrm{a}, \mathrm{b}, \mathrm{c}, \mathrm{d}, \mathrm{e}, \mathrm{f}}$ Mean values with unlike letters were significantly different from each other $(P<0 \cdot 05)$. B, baseline; $Z P$, zinc- and proteindeficient; P, protein-deficient; Z, zinc-deficient; E, energy-deficient; C, control.

\section{Discussion}

In the present study, $\mathrm{Zn}$, energy and protein deficiencies had divergent negative effects on muscle mass (Fig. 4(A)), MFD (Fig. 4(C) and (D)) and serum IGF-1 (Fig. 2(B)). The reductions in gastrocnemius muscle mass in the deficient groups were proportional to body weight (Fig. 4(B)) but they did not reflect the differences in MFD. The $\mathrm{Zn}$, protein and combined $\mathrm{Zn}+$ protein deficiencies arrested $\mathrm{T} 1-$ and T2-MFD growth at baseline measurements, and energy deficiency compromised T2-MFD, but not T1-MFD. Serum IGF-1 concentrations did not parallel these differences in MFD, and in the context of this experiment, there was a greater reduction of serum IGF-1 concentrations in energytype malnutrition ( $Z$ and $E$ groups) than protein-type malnutrition ( $\mathrm{ZP}$ and $\mathrm{P}$ groups). The IGF-1-lowering effect of $\mathrm{Zn}$ deficiency in the present study ( $Z$ group) was partially blunted by concomitant protein deficiency ( $Z$ P group; Fig. 2(B)). Typically, IGF-1 levels rely on both protein and $\mathrm{Zn}$ intake ${ }^{(14-17,19,20)}$; thus, the higher serum IGF-1 concentrations in the $\mathrm{Zn}+$ protein-deficient animals compared with the $\mathrm{Zn}$ deficient animals in the present study are surprising. Likewise, the higher femur $\mathrm{Zn}$ concentrations of the $\mathrm{ZP} v$. Z group during the deficiency phase were not anticipated as both groups consumed the same amount of diet with $<1 \mathrm{mg} \mathrm{Zn/kg}$
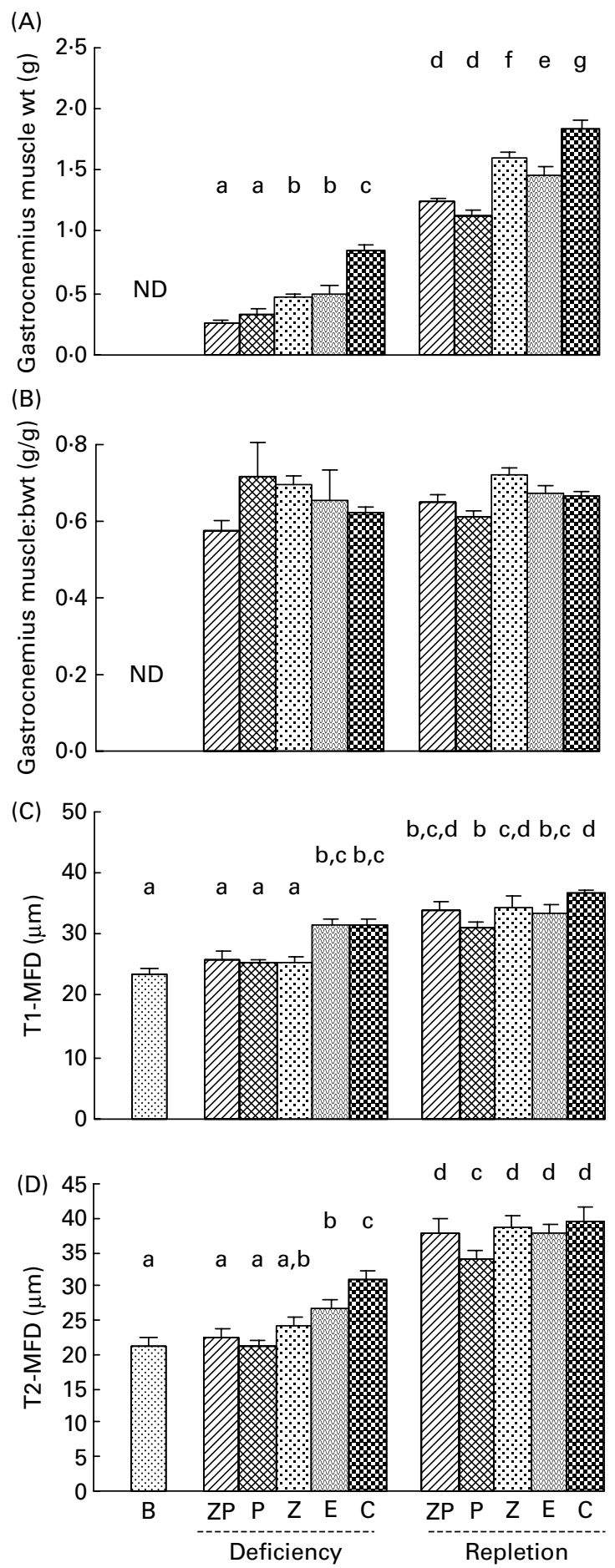

Fig. 4. Effects of dietary zinc, protein and energy deficiencies and repletion on (A) gastrocnemius muscle weight, $(B)$ gastrocnemius muscle:body weight (bwt) ratio, (C) type 1 muscle fibre diameters (T1-MFD) and (D) type 2 muscle fibre diameters (T2-MFD) in growing rats. Values are means, with their standard errors represented by vertical bars (eight animals per group). Main effects (diet, time and diet $\times$ time) were significant for each parameter $(P<0.05)$, but not time for T2-MFD and there were no significant main effects for the muscle:bwt ratio. ${ }^{a, b, c, d, e, f, g}$ Mean values with unlike letters were significantly different from each other $(P<0.05)$. B, baseline; ZP, zinc- and protein-deficient; $P$, protein-deficient; $Z$, zinc-deficient; $E$, energy-deficient; $\mathrm{C}$, control; ND, not determined. 

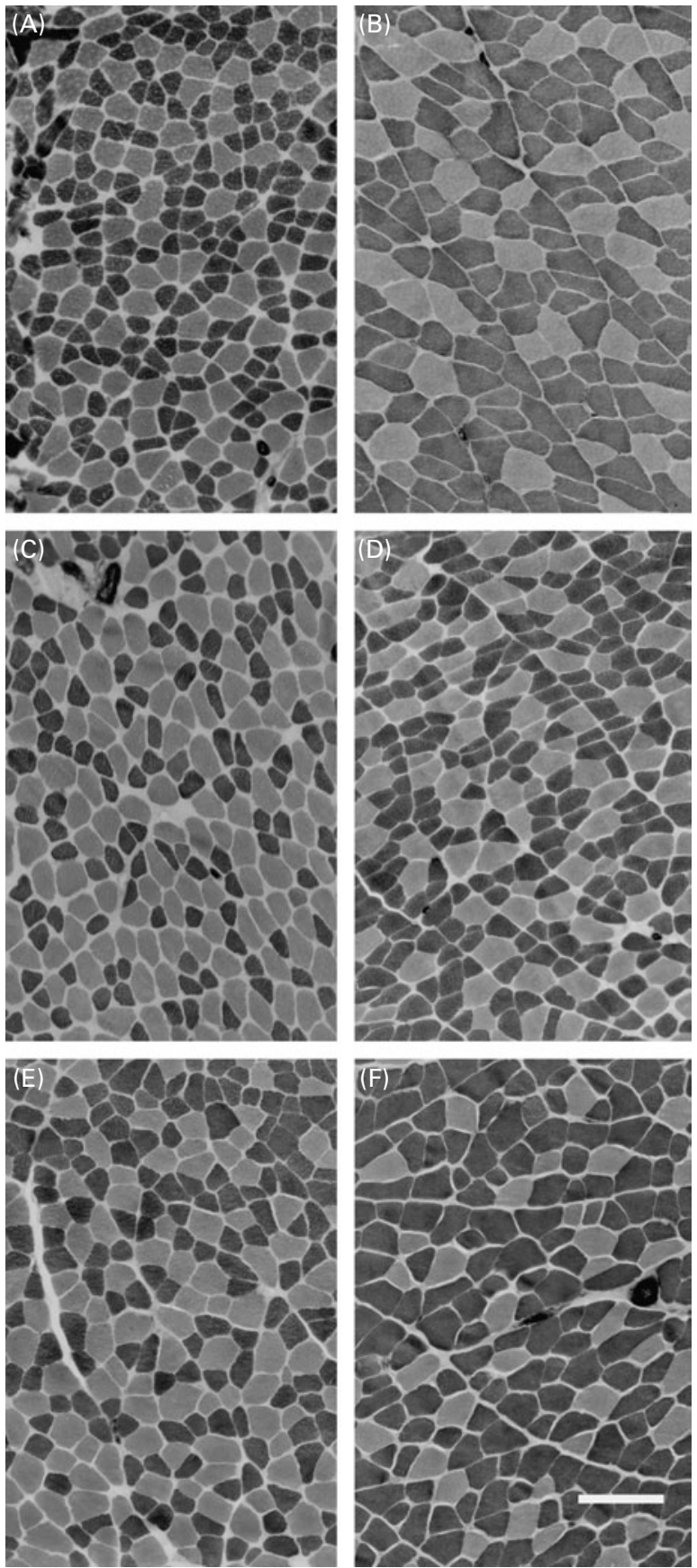

Fig. 5. Representative images of dietary zinc, protein and energy deficiencies on ATPase histochemical staining at $\mathrm{pH} 9.4$ of the gastrocnemius muscle. (A) Baseline group, (B) control group, (C) zinc- and proteindeficient group, (D) protein-deficient group, $(E)$ zinc-deficient group and $(F)$ energy-deficient group. Type 1 muscle fibres (low ATPase activity) are light in colour and type 2 muscle fibres (high ATPase activity) are dark in colour. Scale bar $=100 \mu \mathrm{m}$. The baseline group was 3 weeks old and all other groups were 6 weeks old at the end of the deficiency phase.

as confirmed by atomic absorption spectroscopy. It is possible that the concomitant deficiency of two nutrients, $\mathrm{Zn}$ and protein, results in some type of metabolic efficiency not observed with a single nutrient deficiency. Future studies are needed to investigate IGF-1 mRNA and protein levels in muscle tissue as well as the IGF-1 signalling pathway.
During the deficiency phase, the $\mathrm{ZP}, \mathrm{P}$ and $\mathrm{Z}$ groups had the smallest T1- and T2-MFD but serum IGF-1 concentrations varied six-fold among these groups. The $\mathrm{Z}$ and $\mathrm{E}$ groups had similar serum IGF-1 concentrations (11-22\% of the $C$ group), but T1-MFD was smaller in the $\mathrm{Z}$ group compared with the E group (pair-fed control). It is generally believed that type 2 muscle fibres reflect changes in nutrition and physical activity more readily than type 1 muscle fibres ${ }^{(24)}$. Histochemical staining of muscle sections to quantify T1and T2-MFD provides further characterisation of the consequences of nutritional deficiencies on skeletal muscle and the quality of lean mass recovery with nutritional rehabilitation.

Others have reported reductions in serum IGF-1 concentrations in rodent models of $\mathrm{Zn}$, protein or energy deficiencies $^{(17,19,20)}$, but relationships between IGF-1 and muscle wasting or recovery were not the focus of those studies. When effects of dietary energy and protein were compared, dietary protein was the more influential factor on serum IGF-1 concentrations ${ }^{(17)}$. IGF-1 measurements in serum are relevant to clinical applications; however, serum IGF-1 concentrations do not always reflect tissue IGF-1 status due to the localised production and actions of IGF-1, and the role of binding proteins ${ }^{(22,30)}$. Undernutrition reduces skeletal MFD and cross-sectional area, but fibre number is maintained $^{(31)}$. Failure of type 1 and 2 muscle fibres to grow has previously been reported in the extensor digitorum longus muscle of 25 -week-old rats fed a $1.5 \%$ protein diet for the previous 19 weeks ${ }^{(32)}$.

The recovery data indicated that previous nutritional status and not serum IGF-1 was the primary factor determining the degree of muscle mass and muscle fibre recovery. Although there were differences in gastrocnemius muscle mass recovery ( $\mathrm{ZP}$ and $\mathrm{P}<\mathrm{E}<\mathrm{Z}<\mathrm{C}$; Fig. 4(A)), the ratios for gastrocnemius muscle mass:body weight were equivalent among the groups (Fig. 4(B)). Recovery of MFD was not dependent on recovery of body weight or gastrocnemius muscle mass. The $\mathrm{P}$ and $\mathrm{E}$ groups had better recovery of body weight than the $\mathrm{ZP}$ and $\mathrm{Z}$ groups (Fig. 1(A)); however, the $\mathrm{Z}$ and $\mathrm{ZP}$ groups experienced full recovery of T1-MFD (Fig. 4(C)) and T2MFD (Fig. 4(D)), while the $\mathrm{P}$ group did not for either fibre type and the $\mathrm{E}$ group recovered only T2-MFD compared with the $\mathrm{C}$ group. Although further research is required to understand the effects of nutritional status on IGF-1 signalling in skeletal muscle, there are in vitro data that $\mathrm{Zn}$ treatment activates IGF-1-receptor phosphorylation in H9c2 cardiac cells $^{(33)}$

The higher inguinal fat pad:body weight ratio in the P group after recovery (Fig. 1(B)) suggested that a greater proportion of the weight gain in this group may be due to adipose tissue. The higher fat accretion by the $\mathrm{P}$ and $\mathrm{E}$ groups compared with the $Z$ group during the repletion phase may also explain their better catch-up growth compared with the $\mathrm{Z}$ group (Fig. 1(A) and (B)). Other than achieving expected weight-for-height, children with PEM experience the same incomplete and disorganised recovery of adipose and muscle tissues and muscle histology ${ }^{(3,5,8)}$ as observed in the $\mathrm{P}$ and $\mathrm{E}$ rats. The muscle fibre cross-sectional areas of children 

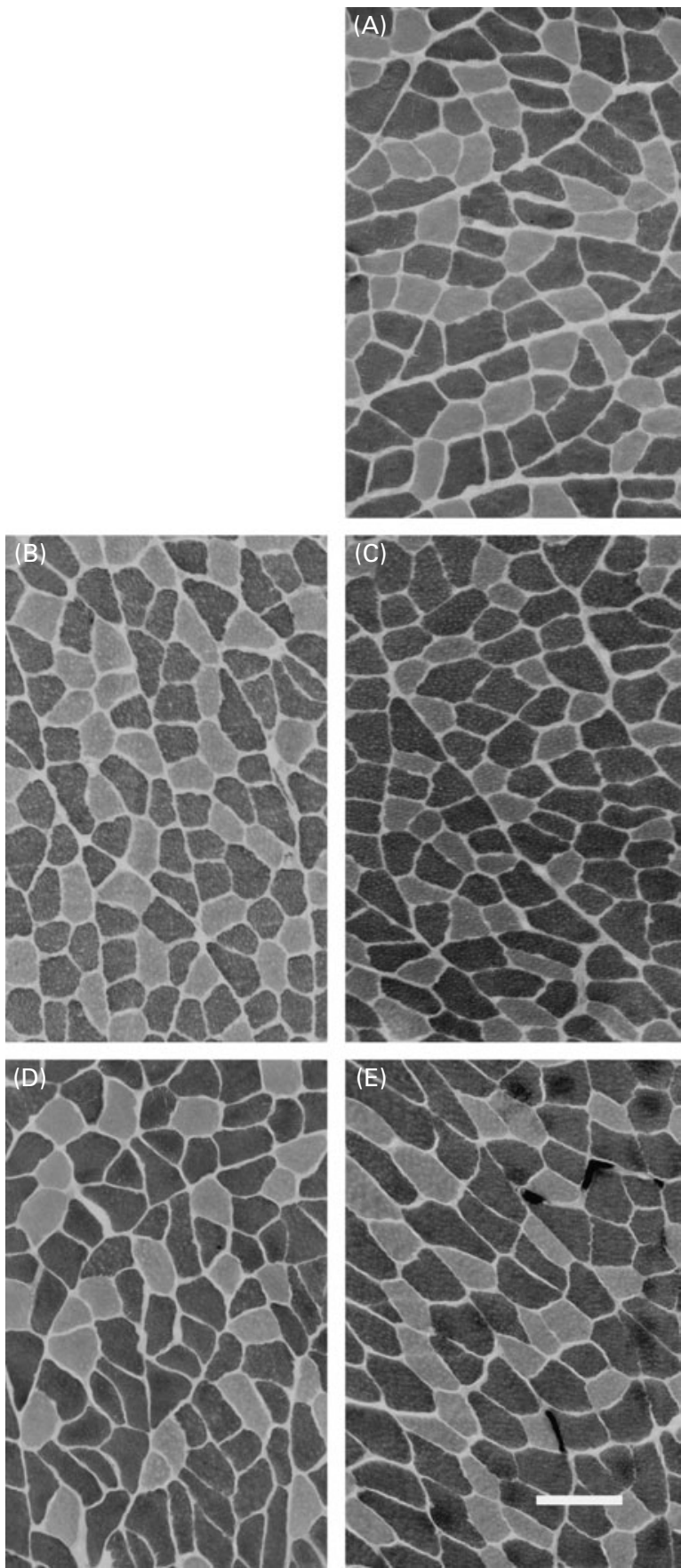

Fig. 6. Representative images of the effects of nutritional repletion on ATPase histochemical staining at $\mathrm{pH} 9.4$ of the gastrocnemius muscle. (A) Control group, (B) zinc- and protein-deficient group, (C) protein-deficient group, (D) zinc-deficient group and (E) energy-deficient group. Type 1 muscle fibres (low ATPase activity) are light in colour and type 2 muscle fibres (high ATPase activity) are dark in colour. Scale bar $=100 \mu \mathrm{m}$. All groups were 9 weeks old.

apparently recovered from PEM were still significantly smaller than age- and sex-matched controls ${ }^{(4,5)}$, and much of the weight gained by children with PEM during compensatory growth was fat ${ }^{(3)}$

The animals in the present study did appear to have muscle recovery relative to their body weight (Fig. 4(B)) despite differences in final body weight and fat accretion (Fig. 1(A) and (B)) among the groups. Glore \& Layman ${ }^{(31)}$ reported that rehabilitation with a $20 \%$ protein diet for 28 weeks was insufficient for the recovery of body weight, skeletal muscle weight, soleus MFD and cross-sectional area (76, 84, 92 and $84 \%$ of control, respectively) in rats that had been feedrestricted for the first $120 \mathrm{~d}$ of life ${ }^{(32)}$. The control diet with $30 \mathrm{mg} \mathrm{Zn/kg} \mathrm{diet,} \mathrm{which} \mathrm{is} \mathrm{designed} \mathrm{for} \mathrm{normal} \mathrm{growing}$ rats, may have been unable to meet the nutritional requirements for full gastrocnemius recovery during compensatory growth. Adequate $\mathrm{Zn}$ during recovery in children $(5-10 \mathrm{mg}$ $\mathrm{Zn} / \mathrm{kg}$ body weight) and mice (40 v. 5 and $10 \mathrm{mg} \mathrm{Zn/kg}$ diet) has been reported to improve rates of weight gain and recovery of lean tissue mass ${ }^{(8,9)}$. The nutritional programming theory has been used to explain the negative impacts of protein and energy deficiencies during fetal and neonatal development on various organ systems later in life; however, there is an absence of studies focusing on skeletal muscle. Both starvation and obesity have been shown to decrease satellite cell proliferation in skeletal muscle ${ }^{(34,35)}$. The present study demonstrating differential effects of previous protein or energy deficiency on recovery of MFD suggests that malnutrition type may have differential effects on impairments in various step(s) for proliferation of satellite cells and the myogenesis process.

In summary, Zn, protein and energy deficiencies resulted in retarded growth and development of the biochemical, cellular and whole-body levels. Previous protein or energy deficiency, but not $\mathrm{Zn}$ or combined $\mathrm{Zn}+$ protein deficiency, limited the recovery of T1-MFD ( $\mathrm{P}$ and $\mathrm{E}$ groups) or T2-MFD ( $\mathrm{P}$ group) during nutritional repletion. The quality of skeletal muscle recovery in the malnourished groups could not be predicted from body weight, muscle mass, serum $\mathrm{Zn}$ or serum IGF-1 concentrations. Further research is required to delineate the effects of sub-optimal postnatal nutrition and nutritional metabolism on skeletal muscle structure and function.

\section{Acknowledgements}

The present study was supported by the Natural Sciences and Engineering Research Council of Canada (grant to C. G. T.) and the University of Manitoba Graduate Fellowship (to A. L. V. P.). A. L. V. P. and C. G. T. contributed to the study design, completion and analysis and manuscript preparation. W. C. H. contributed to the analysis and interpretation of muscle histology. There were no conflicts of interest. Thanks also to the staff of the Science Animal Care facility and the Pathology Laboratory, Health Sciences Centre, Winnipeg, MB, Canada; and Sergio Mejia, Department of Geological Sciences, University of Manitoba for assistance with the image analysis.

\section{References}

1. World Health Organization (2009) Global Health Risks. Mortality and Burden of Disease Attributable to Selected Major Risks. Geneva: WHO. 
2. Graham GG, Cordano A, Blizzard RM, et al. (1969) Infantile malnutrition: changes in body composition during rehabilitation. Pediatr Res 3, 579-589.

3. MacLean WC \& Graham GG (1980) The effect of energy intake on nitrogen content of weight gained by recovering malnourished infants. Am J Clin Nutr 33, 903-909.

4. Montgomery RD (1962) Muscle morphology in infantile protein malnutrition. J Clin Pathol 15, 511-521.

5. Hansen-Smith FM, Picou D \& Golden MH (1979) Growth of muscle fibres during recovery from severe malnutrition in Jamaican infants. Br J Nutr 41, 275-282.

6. Golden MHN \& Golden BE (1981) Plasma Zn, rate of weight gain, and the energy cost of tissue deposition in children recovering from severe malnutrition on cow's milk or soya protein based diet. Am J Clin Nutr 34, 892-899.

7. Golden MHN \& Golden BE (1981) Effect of zinc supplementation on the dietary intake, rate of weight gain, and energy cost of tissue deposition in children recovering from severe malnutrition. Am J Clin Nutr 34, 900-908.

8. Golden BE \& Golden MHN (1992) Effects of zinc on lean tissue synthesis during recovery from malnutrition. Eur J Clin Nutr 46, 697-706

9. Morgan PN, Keen CL, Calvert CC, et al. (1988) Effect of varying dietary zinc intake of weanling mouse pups during recovery from early undernutrition on growth, body composition and composition of gain. J Nutr 118, 690-698.

10. Glore SR, Orth VL, Knehans AW, et al. (1993) Efficacy of dietary zinc supplementation on catch-up growth after protein malnutrition. J Nutr Biochem 4, 281-285.

11. Jennische E \& Olivercrona H (1987) Transient expression of insulin-like growth factor-1 immunoreactivity in skeletal muscle cells during postnatal development in the rat. Acta Physiol Scand 131, 619-622.

12. Zanconato S, Moromisato DY, Moromisato MY, et al. (1994) Effect of training and growth hormone suppression on insulin-like growth factor-1 mRNA in young rats. $J$ Appl Physiol 76, 2204-2209.

13. Adams GR \& Haddad F (1996) The relationships among IGF-1, DNA content and protein accumulation during skeletal muscle hypertrophy. J Appl Physiol 81, 2509-2516.

14. Cesur Y, Yordaman N \& Doğan M (2009) Serum insulin-like growth factor-I and insulin-like growth factor binding protein-3 levels in children with zinc deficiency and the effect of zinc supplementation on these parameters. J Pediatr Endocrinol Metab 22, 1137-1143.

15. Akman I, Arioglu P, Koroglu OA, et al. (2006) Maternal zinc and cord blood zinc, insulin-like growth factor-1, and insulin-like growth factor binding protein-3 levels in smallfor-gestational-age newborns. Clin Exp Obstet Gynecol 33, $238-240$

16. Doherty CP, Crofton PM, Sarkar MA, et al. (2002) Malnutrition, zinc supplementation and catch-up growth: changes in insulin-like growth factor I, its binding proteins, bone formation and collagen turnover. Clin Endocrinol (Oxf) 57, 391-399.

17. Prewitt TE, D'Ercole AJ, Switzer BR, et al. (1982) Relationship of serum immunoreactive somatomedin-C to dietary protein and energy in growing rats. $J$ Nutr 112, 144-150.

18. Thissen JP, Underwood LE, Maiter D, et al. (1991) Failure of insulin-like growth factor-1 (IGF-1) infusion to promote growth in protein-restricted rats despite normalization of serum IGF-1 concentrations. Endocrinology 128, 885-890.

19. Cossack ZT (1986) Somatomedin-C and zinc status in rats as affected by zinc, protein and food intake. BrJ Nutr 56, 163-169.

20. Dorup I, Flyvbjerg A, Everts ME, et al. (1991) Role of insulinlike growth factor-1 and growth hormone in growth inhibition induced by magnesium and zinc deficiencies. BrJ Nutr 66, 505-521.

21. Roth HP \& Kirchgessner M (1994) Influence of alimentary zinc deficiency on the concentration of growth hormone $(\mathrm{GH})$, insulin-like growth factor-1 (IGF-1) and insulin in the serum of force-fed rats. Horm Metab Res 26, 404-408.

22. Ketelslegers JM, Maiter D, Maes M, et al. (1995) Nutritional regulation of insulin-like growth factor-1. Metabolism $\mathbf{4 4}$, $50-57$

23. Mares-Perlman JA, Subar AF, Block G, et al. (1995) Zinc intake and sources in the US adult population: 1976-1980. J Am Coll Nutr 14, 349-357.

24. Sarnat HB (1983) Muscle Pathology and Histochemistry. Chicago, IL: American Society of Clinical Pathologists Press.

25. Reeves PG, Nielsen FH \& Fahey GC (1993) AIN-93 purified diets for laboratory rodents: final report of the American Institute of Nutrition ad hoc writing committee on the reformulation of the AIN-76A rodent diet. J Nutr 123, 1939-1951.

26. Canadian Council on Animal Care (1993) Guide to the care and use of experimental animals. http://www.ccac.ca/ en/CCAC_Programs/Guidelines_Policies/GUIDES/ENGLISH/ toc_v1.htm (accessed 5 July 2010).

27. Dubowitz V \& Brooke MH (1973) Muscle Biopsy: A Modern Approach. Toronto: WB Saunders Co Ltd.

28. Estes ML \& Goss GR (1996) Muscle Biopsy: the Role of the Technologist in Optimum Freezing, Enzyme Histochemistry and Diagnosis. Canadian Society of Laboratory Technologists Congress Winnipeg, Canada.

29. Lepage LM, Giesbrecht J \& Taylor CG (1999) Expression of T lymphocyte $\mathrm{p} 56 \mathrm{lck}$, a zinc-finger signal transduction protein, is elevated by dietary zinc deficiency and diet restriction in mice. J Nutr 129, 620-627.

30. Backeljauw P, Bang P, Dunger DB, et al. (2010) Insulin-like growth factor-I in growth and metabolism. J Pediatr Endocrinol Metab 23, 3-16.

31. Glore SR \& Layman DK (1987) Cellular development of skeletal muscle of rats during recovery from prolonged undernutrition. J Nutr 117, 1767-1774.

32. Oldfors A, Mair WGP \& Sourander P (1983) Muscle changes in protein-deprived young rats. A morphometrical, histochemical, and ultrastructural study. J Neurol Sci 59, 291-302.

33. Lee S, Chanoit G, McIntosh R, et al. (2009) Molecular mechanism underlying Akt activation in zinc-induced cardioprotection. Am J Physiol Heart Circ Physiol 297, H569-H575.

34. Halevy O, Geyra A, Barak M, et al. (2000) Early posthatch starvation decreases satellite cell proliferation and skeletal muscle growth in chicks. $J$ Nutr 130, 858-864.

35. Peterson JM, Bryner RW \& Always SE (2008) Satellite cell proliferation is reduced in muscles of obese Zucker rats but restored with loading. Am J Physiol Cell Physiol 295, C521-C528. 